\title{
www.ijpsonline.com \\ Application of Platelet-rich Plasma in Regenerated Pulp Treatment of Young Permanent Teeth: An Animal Study
}

\author{
X. XI* L. LIU, W. CHEN1 AND G. HAN \\ Department of Stomatology, Harrison International Peace Hospital, Hengshui 053000,1The No. Department of Stomatology, \\ Baoding No.1 Central Hospital, Baoding 071000, China
}

\begin{abstract}
Xi et al: Application of Platelet-Rich Plasma in Regenerated Pulp Treatment of Young Permanent Teeth
Animal experiments were conducted to observe and analyze the therapeutic effect of platelet-rich plasma in regenerated pulp treatment of young permanent teeth, in order to provide valuable guidance on the clinical treatment. Six beagle dogs were selected as study subjects with 54 teeth and 108 root canals. Thirty six teeth were selected as the control group, without any treatment. Another 72 teeth were randomized into the whole blood group (36 teeth) and platelet-rich plasma group (36 teeth) with 72 root canals. The model of periapical periodontitis was established and the $X$ - ray and histological results of the whole blood group and platelet rich plasma group were analyzed using the Fisher exact probability method. After 12 weeks of regenerated endodontic pulp treatment, X-ray examination showed that there was no significant difference between the whole blood group and platelet rich plasma group in terms of periapical shadow reduction, apical hole closure and thickening of root canal wall. Histology results showed that the apical pore part of the root canal in the whole blood group and platelet-rich plasma group was closed and the root canal wall was thickened, the cemenoid tissue deposition occurred in the root canal wall and apical hole and free cemenoid tissue and dental pulp tissue were generated in the root canal. There was no statistical significance between the whole blood group and platelet-rich plasma group in comparison to apical closure, new tissue formation of the root canal wall and endodontic pulp tissue formation. The application of platelet-rich plasma in the treatment of regenerative pulp can make the root of young permanent teeth develop well. If the root periapical tissue fails to bleed to form blood clot in the treatment of regenerative pulp, the stent scheme of platelet-rich plasma is more ideal.
\end{abstract}

Key words: Animal experiment, platelet rich plasma, young permanent teeth, regenerative pulp therapy, therapeutic results

The pulp tissue of young permanent teeth has many functions, such as providing nutrition for teeth and exerting sensory function and is also closely related to the development of teeth. Once the young permanent teeth lose the vitality of the pulp before the root is fully developed, weak root canal wall and increased probability of fracture results. Many factors can cause infection and necrosis of the pulp of young permanent teeth, such as caries, abnormal tooth development and tooth trauma, which will affect the root development to different degrees ${ }^{[1,2]}$. Platelet-rich plasma is a plasma with higher platelet content than normal, which is extracted from autogenous blood and is rich in platelet derived growth factor (PDGF), transformed growth factor (TGF), insulin-like growth factor (IGF), vascular endothelial growth factor (VEGF) and epidermal growth factor (EGF). Platelet-rich plasma is rich in fibrin, fibronectin and boronectin, which attract cells to migrate and can promote tissue repair, regeneration and vascularization. Platelet-rich plasma extracted from autologous blood has currently been widely used in various fields, such as ophthalmology, otolaryngology, sports medicine, neurosurgery, periodontal and jaw defect repair ${ }^{[3,4]}$. In this study, an animal model of young permanent periapical periodontitis of beagle dog was developed to analyze the possible mechanism of regenerative pulp treatment, so as to provide valuable reference for the treatment of regenerative pulp.

Six beagles provided by the Animal Experiment Center of Dalian Medical University, with the average age of $6.2 \pm 0.9$ mo old, 3 males and 3 females were used. The animals had no systemic or oral disease, X-rays showed clear deciduous teeth, young permanent teeth with open apical foramen of double premolars. Drugs and reagents used in this study included, $3 \%$ sodium hypochlorite, glycerin, pentobarbital sodium, minocycline, 
metronidazole, ciprofloxacin, ciprofloxacin II, mineral trioxide aggregates, caviton, glass ionic cement and atecaine hydrochloride injection. The instruments used were, dental X-ray machine, spiral root charger, blood cell analyzer and high-speed low temperature bench centrifuge. Antibiotic paste was prepared on spot by mixing glycerin until becoming thick and creamy ${ }^{[5]}$. The study was carried out with the approval of the animal ethics committee of China medical university.

Six beagles had a total of 54 teeth and 108 root canals, 36 of which were selected as the control group, without any treatment. Another 72 were randomized into the whole blood group (36 teeth) and plateletrich plasma group (36 teeth), with 72 root canals. The tooth simulation of the beagle is shown in fig. 1. The animals were anesthetized and a model of periapical inflammation was established. Three weeks later, $\mathrm{X}$-ray was taken at the root tips to observe whether the periapical membrane was widened or there was shadow around the root tips, so as to establish the model of periapical inflammation. Next, the root canal was sealed. Platelet-rich plasma was extracted, that is, $6 \mathrm{ml}$ of venous blood was collected from the small saphenous vein outside the hind legs of the dog by sterile blood collection needle and vacuum blood collection (including EDTA-k2) and then the plateletrich plasma was separated by secondary centrifugation under aseptic state. Finally, regenerated pulp treatment was performed. X-ray films were taken at 4,8 and $12 \mathrm{w}$ after the treatment with regenerative pulp to observe the continued development of tooth roots ${ }^{[6]}$. After $12 \mathrm{w}$, the experimental animals were sacrificed, jugular vein perfusion was performed with $10 \%$ neutral buffered formalin fixative solution under general anesthesia. The upper and lower jaw bones were removed and tissue blocks were prepared. After that, the tissue blocks were decalcified at room temperature of $10 \%$ EDTA pH 7.2 for $12 \mathrm{w}$. HE staining was performed on tissue masses before observing under microscope. With each root as a separate observation unit, the X-ray and histological results were observed blind by 2 doctors. SPSS 21.0 statistical analysis software was adopted to process data. The measurement data were expressed by means of mean \pm standard deviation, with $t$ test conducted for intergroup comparison. The enumeration data were expressed in terms of natural number (n) and percentage ( $\%$ ), with $\chi^{2}$ for intergroup comparison. The intergroup difference was considered of statistical value when $P<0.05$.

Twelve weeks after the implementation of regenerated

pulp treatment, X-ray examination showed that the shadow around the root tip was significantly reduced and the root tip was closed and the root canal wall was thickened. However, there was no statistically significant difference between the whole blood group and the platelet rich plasma group, $P>0.05$, as shown in Table 1. The tooth development in the control group was normal. The dentin in the inner wall of the root canal and the cementum deposition in the outer wall thickened the root canal wall. The apical part of the root was surrounded by cementum, and the normal pulp tissue and periodontal membrane tissue in the root canal at the apical orifice were communicating. The normal pulp tissue in the root canal was composed of odontoblasts, fibroblasts and blood vessels. The odontoblast cells were attached to the dentin wall. After 3 mo of regenerated pulp treatment, there were significant new tissue formation in the root canals of the whole blood group and the platelet-rich plasma group, and the 2 groups had similar histological manifestations under light microscope, as shown in figs. 2-5. The comparison of histological observation results between the whole blood group and the plateletrich plasma group after treatment is shown in Table 2.

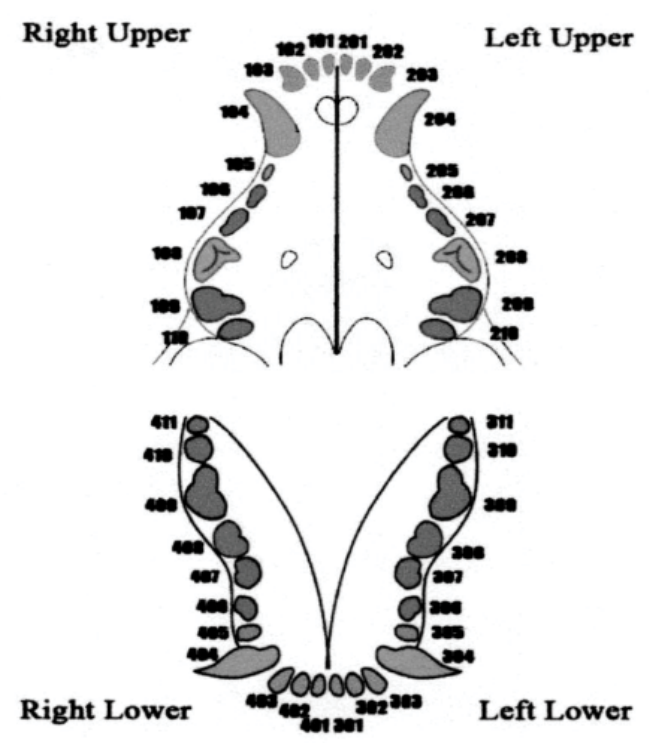

Fig. 1: Simulated dental map of a beagle

TABLE 1: X-RAY EXAMINATION RESULTS OF TWO GROUPS AFTER REGENERATED PULP TREATMENT

\begin{tabular}{lccc}
\hline Index & $\begin{array}{c}\text { Periapical } \\
\text { shadow } \\
\text { reduction }\end{array}$ & $\begin{array}{c}\text { Apical } \\
\text { closure }\end{array}$ & $\begin{array}{c}\text { Thickening } \\
\text { of root canal } \\
\text { wall }\end{array}$ \\
\hline $\begin{array}{l}\text { whole blood } \\
\text { group }\end{array}$ & $36 / 36(100.00)$ & $32 / 36(88.89)$ & $23 / 36(63.89)$ \\
$\begin{array}{l}\text { platelet-rich } \\
\text { plasma group } \\
P\end{array}$ & $36 / 36(100.00)$ & $22 / 36(61.11)$ & $24 / 36(66.67)$ \\
\hline
\end{tabular}




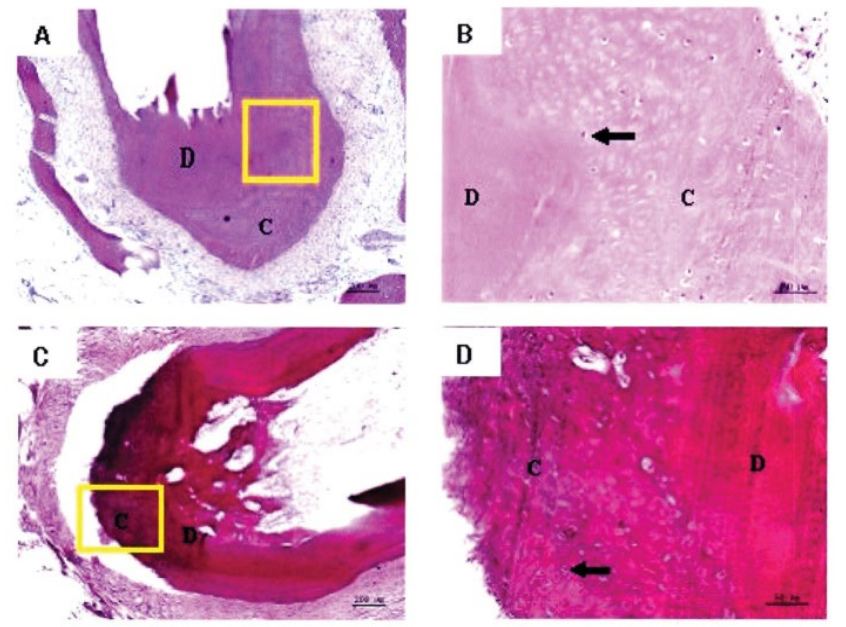

Fig. 2: Histology of apical closure

Histological manifestations of apical closure after treatment in whole blood group and platelet rich plasma group
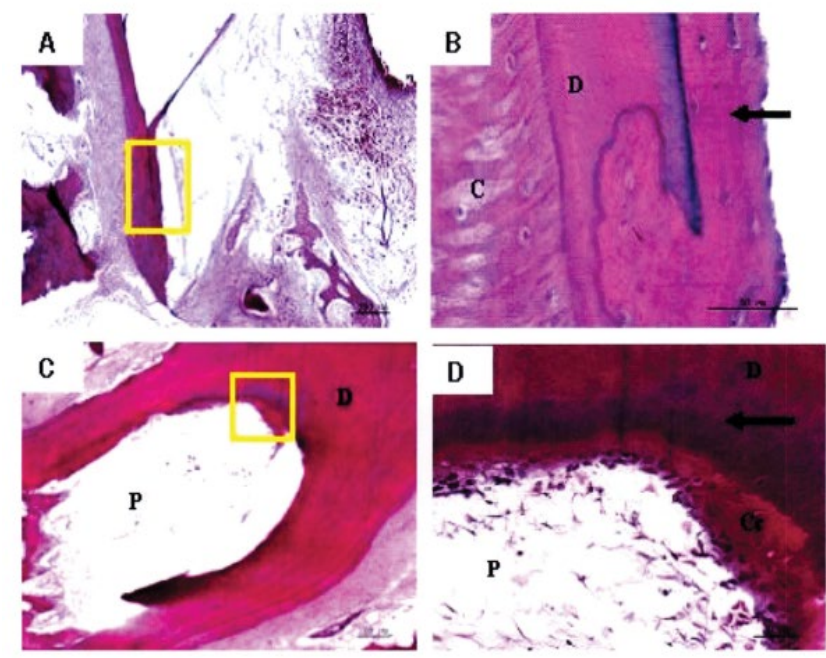

Fig. 3: Histology of root canal wall thickening

Histological manifestations of root canal wall thickening after treatment between whole blood group and platelet rich plasma group

Platelet-rich plasma is a good substitute for blood clot stents and has been used in some clinical cases with satisfactory results. In this study, X-ray and histological observation were carried out in animal experiments to explore the root development and tissue properties of tooth regeneration after the application of platelet-rich plasma in regenerative pulp treatment. Preoperatively, each beagle was fasted for $12 \mathrm{~h}$ and then intramuscular injection of sumimide II $(0.04 \mathrm{ml} / \mathrm{kg})$ into the left hip and intramuscular injection of $3 \%$ pentobarbital sodium $(0.5 \mathrm{ml} / \mathrm{kg})$ into the right hip were given. While the animals were anesthetized, the following experiments were performed and the anaesthesia time was noted. Intramuscular injection of chlorhexidine II and $3 \%$ pentobarbital sodium per hour was given on the buttocks, respectively. Secondly, a model of periapical inflammation was established. Under general anesthesia, beagle's mouth was opened and the surface of the teeth was scraped to collect dental plaque which
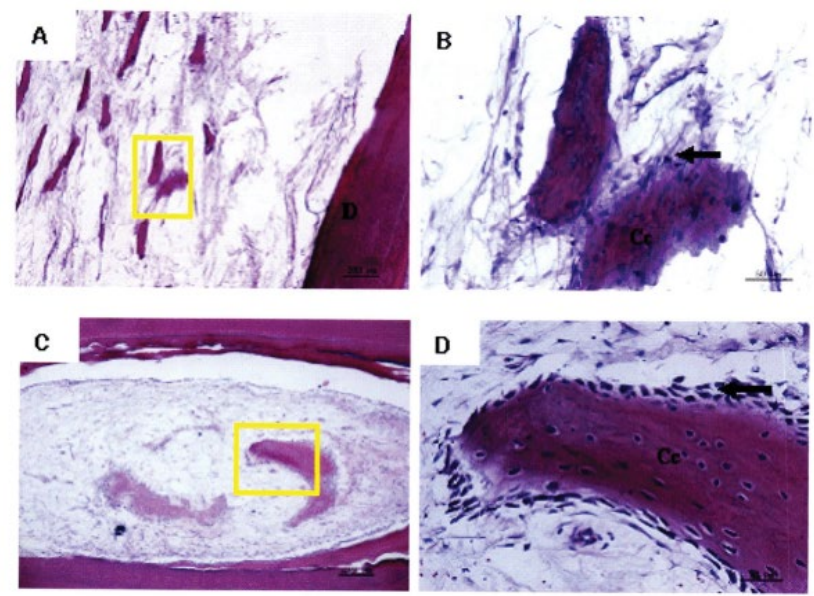

Fig. 4: Histology of free cellular cementitious tissue in root canal

Histological manifestations of free cellular cementitious tissue in root canal between the whole blood group and the platelet rich plasma group after treatment

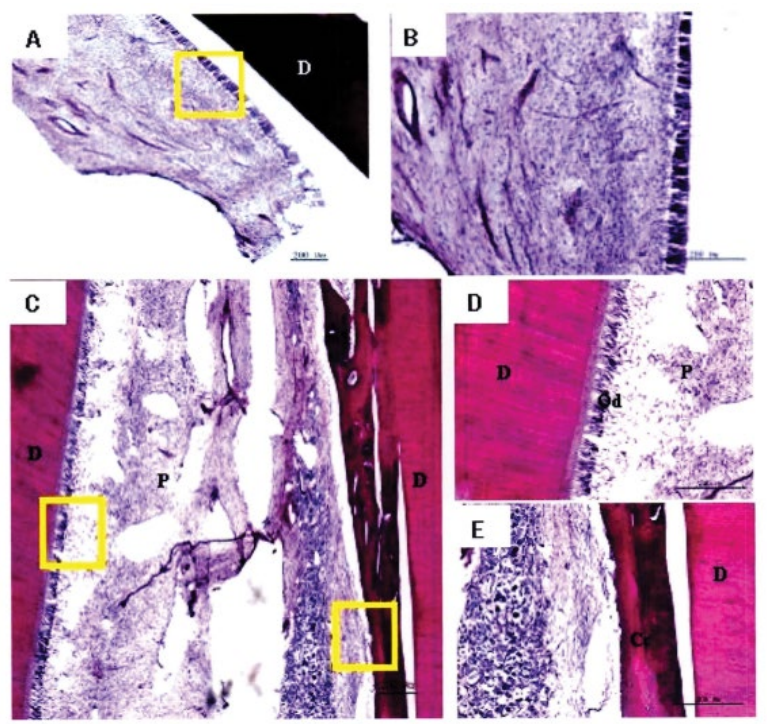

Fig. 5: Histology of endodontic cells in medullary tissue Histological manifestations of endodontic cells in medullary tissue between the whole blood group and the platelet rich plasma group after treatment

\begin{tabular}{|c|c|c|c|}
\hline $\begin{array}{l}\text { TABLE } \\
\text { BETWEEN } \\
\text { RICH PLASN }\end{array}$ & $\begin{array}{l}\text { 2: HISTOLC } \\
\text { VHOLE BLOOL } \\
\text { MA GROUP AF }\end{array}$ & $\begin{array}{l}\text { GICAL } \\
\text { GROUPA } \\
\text { TER TREA }\end{array}$ & $\begin{array}{l}\text { BSERVATION } \\
\text { D PLATELET- } \\
\text { MENT }\end{array}$ \\
\hline Index & Apical closure & $\begin{array}{l}\text { Forming } \\
\text { new tissue } \\
\text { in the root } \\
\text { canal wall }\end{array}$ & $\begin{array}{c}\text { Forming } \\
\text { endodontic } \\
\text { medullary } \\
\text { tissue }\end{array}$ \\
\hline $\begin{array}{l}\text { whole blood } \\
\text { group }\end{array}$ & $23 / 35(65.71)$ & $\begin{array}{c}27 / 35 \\
(77.14)\end{array}$ & $31 / 35(88.57)$ \\
\hline $\begin{array}{l}\text { platelet-rich } \\
\text { plasma group }\end{array}$ & $22 / 30(73.33)$ & $\begin{array}{l}27 / 30 \\
(90.00)\end{array}$ & $28 / 30(93.33)$ \\
\hline$P$ & 1.00 & 0.84 & 1.00 \\
\hline
\end{tabular}


was mixed with saline. A high-speed mobile phone and a split-drill were used to open and mash the teeth of the whole blood group and the platelet-rich plasma group. Cotton balls dipped in normal saline with dental plaque were placed in the root canal, with zinc oxide combined with zinc phosphate cement at the bottom ${ }^{[7,8]}$ and the glass ion cement closed the hole for treatment. Analgesics were given after the operation. Three weeks later, X-ray was taken at the root tips to observe whether the periapical membrane was widened or there was shadow around the root tips, so as to establish the model of periapical inflammation. Next, the root canal was sealed. The root canals of the teeth in the whole blood group and the platelet-rich plasma group were washed slowly with $3 \%$ sodium hypochlorite and normal saline successively and then the antibiotic paste was introduced into the root canals with a spiral root charger and stopped at the root canal mouth. Upper zinc oxide + zinc phosphate cement base, glass ion cement closed the hole, X-ray was taken at root tip for observation for $3 \mathrm{w}$. Platelet rich plasma was extracted and regenerated pulp treatment was performed. Three weeks after the root canal was sealed, X-ray was taken to understand the disappearance of shadow around the root tip. The root canals were rinsed with $3 \%$ sodium hypochlorite and sterile saline to flush out the antibiotic paste and the root canals were dried with sterile paper tips.

For animals in the whole blood group, the \#15 root canal stimulated the periapical tissues to bleed, which made the blood stop at the enamel cementum boundary and covered the mineral trioxide aggregates after the formation of blood clots. For the platelet-rich plasma group, the obtained platelet-rich plasma was injected into the root canal to the enamel cementum boundary and the mineral trioxide aggregates were covered after coagulation. After X-ray film was taken to determine the sealing effect, glass ion cement was filled. X-rays were taken at 4,8 , and $12 \mathrm{w}$ after regenerated pulp treatment to observe the continued development of the root.

The results showed that the application of platelet-rich plasma in the treatment of regenerative dental pulp could make the root of young permanent teeth continue to develop, which was manifested as the thickening of the root canal wall and the closure of the apical foramen. In regenerative pulp therapy, cementitious and medullary tissues are newly formed in the root canals of the scaffolds with blood clots and platelet-rich plasma. For the affected teeth, which failed to bleed and form blood clots by stimulating the periapical tissue, plateletrich plasma is a new choice. These observations are in line with previous studies ${ }^{[9-12]}$.

In conclusion, histological observation showed that in the whole blood group and the platelet-rich plasma group, both the inner wall and the apical part of the tooth root canal had mineralized tissue deposition, which resulted in thickening of the root canal wall and closure of the apical pore. The mineralized tissues formed were all cementitious tissues rather than dentinoid tissues and there were cementitious cells. There was no significant difference between the 2 groups in promoting the thickening of root canal wall. Experiments have proved that free mineralized tissue can be formed in the root canal after regenerative pulp treatment and this tissue is surrounded by cementitious cells, which may lead to further growth of mineralized tissue and even cause calcification obstruction in the root canal. In addition, although platelet-rich plasma has been widely used in clinical treatment in recent years, the extraction methods of platelet-rich plasma are different, so the concentrations of platelets and white blood cells in platelet-rich plasma are different. Up to now, there is still no unified extraction method for platelet-rich plasma used in clinical treatment and the role of various growth factors in the treatment of regenerative dental pulp needs to be further studied.

\section{REFERENCES}

1. Zhou WF, Zhu L, Jiang XF, Wang YB. Application of radiofrequency combined with platelet rich plasma in repairment of meniscus white tear. J Clini Rehab Tissue Eng Res 2017; 21(20):3123-8.

2. Fu JX, Wang SS. Mechanism and application of autologous platelet-rich plasma in the treatment of bone joint and sports injury. J Clini Rehab Tissue Eng Res 2017; 21(30):4908-14.

3. Ofori-Kwakye K. Development and evaluation of natural gum-based extended release matrix tablets of two model drugs of different water solubilities by direct compression. Saudi Pharm J 2016;24(1):82-91.

4. Attari Z. Enhanced ex vivo intestinal absorption of olmesartan medoxomil nanosuspension: Preparation by combinative technology. Saudi Pharm J 2016;24(1):57-63.

5. Li M, Liu H, Zhang YF, Di ZL, Zhang JH, He ZY. Preliminary follow-up results of autologous osteochondral transplantation combined with platelet rich plasma in the treatment of cartilage defects of knee joint. Chin J Bone Joint Inj 2018;33(02):138-140.

6. Li WF, Zhan L, Li ZS, Li XF, Yang Y. Effect of platelet rich plasma combined with bone fragments on tendon-bone healing and biomechanics after anterior cruciate ligament reconstruction in rabbits. Shaanxi Med J 2018;47(09):1095-8.

7. Richard AB, Christopher JM, Philip DB, Alexander DS, James MM, Christopher PG. Risk stratification for ST segment elevation myocardial infarction in the era of primary percutaneous coronary intervention. World J Cardiol 2014;6(08):865-72.

8. Zhou H, He XY, Zhuang SW, Wang J, Lai Y, Qi WG, et al. 
Clinical and procedural predictors of no-ref low in patients with acute myocardial infarction after primary percutaneous coronary intervention. World J Emerg Med 2016;5(02):96-102.

9. Peng XW, Yang Y, Yu CH, Yin XL. Experimental study of temperature sensitive platelet - rich plasma gel in the treatment of corneal alkali burn. Recent Adv Ophthalmol 2016;36(04):314-7.

10. Gao W, Baig AQ, Ali H, Sajjad W, Farahani MR. Margin based ontology sparse vector learning algorithm and applied in biology science. Saudi J Biol Sci 2017;24(1):132-8.

11. Abdel MS. Design and synthesis of some substituted thiazolo $[3,2-a]$ pyrimidine derivatives of potential biological activities. Saudi Pharm J 2016;24(2):119-32.
12. Naeem S, Akhtar S, Lei Z, Lu K, Zafar S, Ahmed A, et al. Cytotoxic and acute toxicity studies of isoniazid derivatives. Pak J Pharm Sci 2017;30S(6):2411-5

This is an open access article distributed under the terms of the Creative Commons Attribution-NonCommercial-ShareAlike 3.0 License, which allows others to remix, tweak, and build upon the work non-commercially, as long as the author is credited and the new creations are licensed under the identical terms

This article was originally published in a special issue: Special issue on "Animal Models \& Experimental Medicine"

Indian J Pharm Sci 2020:82(1)spl issue4;83-87 